Expression of Concern

\title{
Expression of Concern: Refat et al. Antioxidant, Antigenotoxic, and Hepatic Ameliorative Effects of Quercetin/Zinc Complex on Cadmium-Induced Hepatotoxicity and Alterations in Hepatic Tissue Structure. Coatings 2021, 11, 501
}

\author{
Coatings Editorial Office
}

check for

updates

Citation: Coatings Editorial Office. Expression of Concern: Refat et al. Antioxidant, Antigenotoxic, and Hepatic Ameliorative Effects of Quercetin/Zinc Complex on Cadmium-Induced Hepatotoxicity and Alterations in Hepatic Tissue Structure. Coatings 2021, 11, 501. Coatings 2021, 11, 1112. https:// doi.org/10.3390/coatings11091112

Received: 13 September 2021 Accepted: 13 September 2021 Published: 15 September 2021

Publisher's Note: MDPI stays neutral with regard to jurisdictional claims in published maps and institutional affiliations.

Copyright: (C) 2021 by the author. Licensee MDPI, Basel, Switzerland. This article is an open access article distributed under the terms and conditions of the Creative Commons Attribution (CC BY) license (https:// creativecommons.org/licenses/by/ $4.0 /)$.
MDPI, St. Alban-Anlage 66, 4052 Basel, Switzerland; coatings@mdpi.com

Following acceptance of the Special Issue article by the Guest Editor, El-Sayed Abd El-Aziz, concerns were raised regarding the integrity of the peer review process [1].

The journal is therefore issuing this expression of concern to alert readers to significant concerns regarding the integrity of the peer review process of the article cited above.

The journal is currently investigating the peer review process of all articles published in the Special Issue, and readers will be updated on the outcome of the investigation where necessary.

The authors have been notified about this Expression of Concern.

\section{Reference}

1. Refat, M.S.; Hamza, R.Z.; A. Adam, A.M.; Saad, H.A.; Gobouri, A.A.; Azab, E.; Al-Salmi, F.A.; Altalhi, T.A.; Khojah, E.; Gaber, A.; et al. Antioxidant, Antigenotoxic, and Hepatic Ameliorative Effects of Quercetin/Zinc Complex on Cadmium-Induced Hepatotoxicity and Alterations in Hepatic Tissue Structure. Coatings 2021, 11, 501. [CrossRef] 